\title{
Andrographolide, an Antioxidant, Counteracts Paraquat- Induced Mutagenesis in Mammalian Cells
}

\author{
Preechaya Tajai $^{1 *}$, Tawit Suriyo ${ }^{2,3}$, Nuchanart Rangkadilok ${ }^{2,3}$, Bogdan I Fedeles $^{4}$, \\ John M Essigmann ${ }^{4}$, Jutamaad Satayavivad ${ }^{2,3}$
}

\begin{abstract}
Paraquat (1,1'-dimethyl, 4,4'-bipyridinium dichloride; PQ), a commonly used herbicide worldwide, is both toxic and mutagenic. The mutagenic effect of PQ stems from its ability to redox-cycle, generating oxidative stress and subsequently oxidative DNA damage, which miscodes when replication is attempted. Andrographolide $\left(\mathrm{AP}_{1}\right)$, the major constituent in the leaves of the herbaceous plant Andrographis paniculata, is a diterpenoid with reported antioxidant activity. The present study employed the mammalian cell line AS52 to investigate the protective effect of AP $_{1}$ against PQ-induced mutagenesis. $\mathrm{AP}_{1}$ induced cytotoxicity in AS52 cells in a dose-dependent manner $\left(\mathrm{IC}_{50}=15.7 \mu \mathrm{M}\right)$, which allowed the selection of a non-lethal dose for the mutagenesis studies. While PQ was mutagenic in AS52 cells as evidenced by the increased levels of 6-TGr mutants, $\mathrm{AP}_{1}$ by itself did not increase the mutation frequency. However, co-treatment with $\mathrm{AP}_{1}(1-5 \mu \mathrm{M})$ or the antioxidant $\mathrm{N}$-acetylcysteine $(2 \mathrm{mM})$ almost completely counteracted the mutagenicity of PQ $(10-100 \mu \mathrm{M})$ in AS52 cells. Taken together, these findings suggest that $\mathrm{AP}_{1}$, and likely by extension, A. paniculata extracts, are effective antioxidants that can protect against PQ-induced mutations, and thus could be a promising alternative treatment for PQ poisoning.
\end{abstract}

Keywords: Andrographolide- antioxidant- pesticide- paraquat- environmental mutagen- carcinogen

Asian Pac J Cancer Prev, 22, Anticancer Activity of Natural Compounds: HOW's on Methods and Reports Suppl, 3-8

\section{Introduction}

Paraquat (1,1'-dimethyl, 4,4'-bipyridinium dichloride; PQ) is one of the most widely used herbicides especially in developing countries including Thailand (Cocheme and Murphy, 2008; Blanco-Ayala et al., 2014; Tajai et al., 2018). Its toxic effects are believed to stem from its ability to generate intracellular reactive oxygen species (ROS) through redox cycling and disrupt the mitochondrial electron transport chain (Cocheme and Murphy, 2008; Blanco-Ayala et al., 2014). An imbalance in the redox state of cells results in extensive mitochondrial damage and cell toxicity (Speit et al., 1998; Cocheme and Murphy, 2008; Blanco-Ayala et al., 2014). Epidemiological studies suggest that PQ has mutagenic and carcinogenic properties (Jee et al., 1995; Wesseling et al., 1996). The mutagenic and genotoxic properties of PQ have also been documented in in vitro studies (Speit et al., 1998; Jovtchev et al., 2010; Tajai et al., 2018). By generating ROS that can induce oxidative DNA lesions such as the mutagenic base 8-oxoguanine (8OG), PQ can induce G to T transversion mutations (Tajai et al., 2018). Our previous report showed that the mutagenicity of PQ increases significantly in our genetically engineered AS52 cell culture system that lacks the DNA repair proteins required to repair $8 \mathrm{OG}$. This result suggests that genomic accumulation of $8 \mathrm{OG}$ is the main driver of PQ-induced mutagenesis (Tajai et al., 2018).

Several studies recommend antioxidant therapy for the treatment of PQ poisoning (Kim et al., 2003; Blanco-Ayala et al., 2014; Ortiz et al., 2016). In support of this view, our previous work demonstrates that the co-treatment with antioxidants such as N-acetylcysteine (NAC) alleviates the mutagenicity of PQ (Tajai et al., 2018). Many other natural or artificial antioxidants, such as silymarin, quercetin, ellagic acid, and L-ascorbic acid have been proposed as potential treatments for PQ poisoning. These antioxidants act either by directly scavenging ROS or by activating oxidative stress response pathways, such as upregulating the expression of Nrf2 (nuclear factor erythroid-2related factor 2) transcription factor and increasing the levels of antioxidant enzymes (e.g., catalase, superoxide dismutases, glutathione-S-transferases) (Blanco-Ayala et al., 2014).

Andrographis paniculata has been traditionally used as an alternative medicine especially in the Southeast Asian countries including Thailand (Yoopan et al., 2007; Suriyo

${ }^{1}$ Faculty of Pharmacy, Payap University, Chiang Mai 50000, Thailand. ${ }^{2}$ Laboratory of Pharmacology, Chulabhorn Research Institute, Bangkok 10210, Thailand. ${ }^{3}$ Center of Excellence on Environmental Health and Toxicology, Ministry of Education, Bangkok 10210, Thailand. ${ }^{4}$ Departments of Biological Engineering and Chemistry, and Center for Environmental Health Sciences, Massachusetts Institute of Technology, Cambridge, Massachusetts 02139, USA. *For Correspondence: tapreechaya@gmail.com 
et al., 2014). Given its broad range of pharmacological activities, $A$. paniculata has been used for treating various diseases such as upper respiratory tract infection, fever, common cold, and inflammation (Yoopan et al., 2007; Suriyo et al., 2014; Wong et al., 2016). The major constituent in $A$. paniculata leaves and stems extracts is andrographolide $\left(\mathrm{AP}_{1}\right)$, a diterpenoid reported to exhibit anti-inflammatory (Sheeja et al., 2006; Low et al., 2015), antioxidant (Sheeja et al., 2006; Chen et al., 2012; Low et al., 2015), and anticancer activities (Sheeja and Kuttan, 2007; Al-Henhena et al., 2014; Suriyo et al., 2014; Monger et al., 2017). In terms of mechanism, $A_{1}$ has been shown to scavenge free radicals and inhibit xanthine oxidase and lipid peroxidation (Lin et al., 2009). Moreover, AP potently up-regulates the mRNA expression of Nrf2 (Wong et al., 2016), which subsequently drives the antioxidant properties of $\mathrm{AP}_{1}$. Given these biological activities, we hypothesized that $\mathrm{AP}_{1}$ can protect mammalian cells from the mutagenic effects of PQ.

In this study, AS52 cells are employed to investigate the protective effect of $\mathrm{AP}_{1}$ against $\mathrm{PQ}$-induced mutations. AS52 cells, a Chinese hamster ovary ( $\mathrm{CHO})$ cell line, are a versatile tool for measuring mutagenesis in mammalian cells. This cell line is engineered to carry the bacterial xanthine-guanine phosphoribosyltransferase $(g p t)$ gene, while lacking the native homologous hprt gene. Using a forward mutagenesis assay, gpt mutants in AS52 cells can be selected by their ability to grow in the presence of 6-thioguanine (6-TG) (Tajai et al., 2018).

\section{Materials and Methods}

\section{Cell culture and chemicals}

$\mathrm{AP}_{1}$ (purity 98\%) was isolated from $A$. paniculata and purified in-house according to our previous report (Pholphana et al., 2013). AS52 cells were kindly provided by Dr. Gerald N. Wogan (Massachusetts Institute of Technology, USA). AS52 cells were maintained in Ham's F-12 medium (Gibco, USA) supplemented with $10 \%$ heat-inactivated $\left(56^{\circ} \mathrm{C}\right.$ for 30 minutes $)$ fetal bovine serum (FBS) (Merck Millipore, Germany), 100 units/ml penicillin, $100 \mu \mathrm{g} / \mathrm{ml}$ streptomycin, and $2 \mathrm{mM} \mathrm{L}$-glutamine (Gibco) in a humidified $5 \% \mathrm{CO}_{2}$ incubator at $37^{\circ} \mathrm{C}$. AS52 cells were cultured in the presence of mycophenolic acid (MPA) (Sigma-Aldrich, USA) for 7 days in order to remove the spurious or pre-existing 6-thioguanine resistant (6-TGR) mutants. The MPA-containing medium was the complete medium (above) supplemented with $10 \mu \mathrm{g} / \mathrm{ml}$ MPA, $250 \mu \mathrm{g} / \mathrm{ml}$ xanthine (Sigma-Aldrich), $22 \mu \mathrm{g} / \mathrm{ml}$ adenine (Sigma-Aldrich), $11 \mu \mathrm{g} / \mathrm{ml}$ thymidine (SigmaAldrich), and $1.2 \mu \mathrm{g} / \mathrm{ml}$ aminopterin (Sigma-Aldrich). Thereafter, cells were maintained in complete medium plus $11.5 \mu \mathrm{g} / \mathrm{ml}$ xanthine, $3 \mu \mathrm{g} / \mathrm{ml}$ adenine and $1.2 \mu \mathrm{g} /$ $\mathrm{ml}$ thymidine for 3 additional days (Tindall et al., 1986; Tindall and Stankowski, 1989; Wattanawaraporn et al., 2012; Tajai et al., 2018). All experiments in this study were carried out within 10 passages after the MPA treatment. Paraquat, 6-thioguanine, hydrogen peroxide, and N-Acetyl-L-cysteine were purchased from Sigma-Aldrich.
Determination of cell viability by the TM assay

AS52 cells were seeded in 96-well plates $(2,500$ cells/well) and allowed to attach for $24 \mathrm{~h}$. Subsequently, cells were treated with various concentrations of $\mathrm{AP}_{1}$ (1-50 $\mu \mathrm{M})$ for $24 \mathrm{~h}$. Cell viability was determined by adding to each well $10 \mu \mathrm{l}$ of TM cell viability reagent (Invitrogen, USA) and incubating at $37^{\circ} \mathrm{C}$ for 30 minutes as recommended by the manufacturer. Fluorescence intensity was recorded at $560 \mathrm{~nm}$ excitation/590 nm emission using a SpectraMax M3 microplate reader. The data were then expressed as the percentage of cell viability relative to the control group (untreated cells).

\section{gpt mutation assay}

AS52 cells were seeded in 6 -well plates $\left(5 \times 10^{5}\right.$ cells/well) and cultured for $24 \mathrm{~h}$ to enable cell attachment. Then, cells were treated with different concentrations of PQ $(10,25,50$, and $100 \mu \mathrm{M})$ for $24 \mathrm{~h}$, hydrogen peroxide $\left(\mathrm{H}_{2} \mathrm{O}_{2}\right)(100 \mu \mathrm{M})$ for $1 \mathrm{~h}$ as positive control (Kim et al., $2003), \mathrm{AP}_{1}(1,5 \mu \mathrm{M})$ for $24 \mathrm{~h}, \mathrm{NAC}(2 \mathrm{mM})$ for $24 \mathrm{~h}$, and the combinations of $\mathrm{PQ}+\mathrm{AP}_{1}$ and $\mathrm{PQ}+\mathrm{NAC}$ for $24 \mathrm{~h}$. After treatment, cells were trypsinized and cytotoxicity was assessed by trypan blue exclusion. Treated cells were then maintained in complete medium for 7 days in order to allow full expression of the gpt mutant phenotype. Thereafter, treated cells $\left(5 \times 10^{5}\right.$ cells $)$ were suspended in $100 \mathrm{ml}$ of complete medium containing $10 \mu \mathrm{M}$ 6-TG to select 6-TG resistant (6-TGR) colonies and seeded at a density of $5 \times 10^{4}$ cells $/ 100 \mathrm{~mm}$ dish (10 dishes/ group). Simultaneously, treated cells $\left(2.5 \times 10^{3}\right.$ cells $)$ were suspended in $50 \mathrm{ml}$ of complete medium without 6-TG (non-selective conditions) to estimate plating efficiency (PE) and seeded at a density of 500 cells $/ 100 \mathrm{~mm}$ dish (5 dishes/group). After incubation for 2 weeks, colonies were stained with $0.5 \%$ crystal violet in $25 \%$ methanol in water and only colonies with $\geq 50$ cells were counted (Tindall et al., 1986; Tindall and Stankowski, 1989; Wattanawaraporn et al., 2012; Tajai et al., 2018). Plating efficiency (PE) and mutation frequency (MF) were calculated as follows:

$\mathrm{PE}=$ Number of colonies/Number of seeded cells

MF $=$ Number of 6-TGR colonies/(Number of seeded cells $\mathrm{x}$ PE)

\section{Statistical analysis}

The data from at least three independent experiments were presented as the mean \pm SEM. Student's t test was used to determine the statistical significance of differences in cell viability and mutation frequencies between experimental and control groups. Analyses were done using GraphPad Prism 7 (Graphpad Software, Inc.) and $\mathrm{p} \leq 0.05$ was considered statistically significant.

\section{Results}

PQ generates ROS such as superoxide anion $\left(\mathrm{O}_{2}^{\bullet-}\right)$, hydrogen peroxide $\left(\mathrm{H}_{2} \mathrm{O}_{2}\right)$, and hydroxyl radical $(\cdot \mathrm{OH})$ through redox cycling. An imbalance between the rate of free radical production and the rate of their elimination by the cellular defense mechanisms manifests as oxidative stress, which results in oxidative damage to DNA that 
<smiles>[R]OC(=O)[C-]([CH])C</smiles>

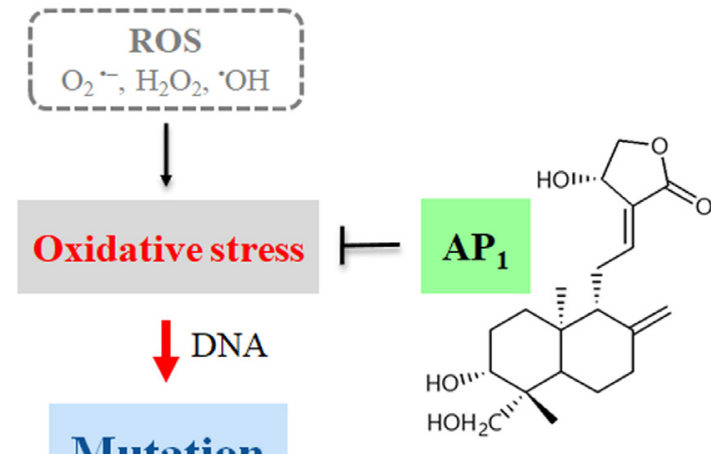

Figure 1. A Schematic of the Mechanism of PQ-Induced Mutations and the Protective Effect of Antioxidants. The present work demonstrates that $\mathrm{AP}_{1}$ is sufficient to alleviate the mutagenic properties of $\mathrm{PQ}$.

can lead to mutations (Speit et al., 1998; Cocheme and Murphy, 2008; Tajai et al., 2018). Our previous report demonstrated that the formation of ROS and the genomic accumulation of oxidative DNA lesions (8OG) are the main drivers of PQ-induced mutagenesis (Tajai et al., 2018). The key finding of the present study is that supplementation with antioxidants such as $\mathrm{AP}_{1}$ and NAC diminishes the oxidative stress levels and consequently the level of mutagenesis induced by PQ (Figure 1).

\section{AP1 induced cytotoxicity in AS52 cells.}

$\mathrm{AP}_{1}$ induced cytotoxicity in AS52 cells in a dose-dependent manner (Figure 2). Cells were treated with various concentrations of $\mathrm{AP}_{1}(1-50 \mu \mathrm{M})$ and their viability evaluated after $24 \mathrm{~h}$. $\mathrm{AP}_{1}$ treatment led to a significant decrease in cell survival $($ IC50 $=15.71 \mu \mathrm{M})$;

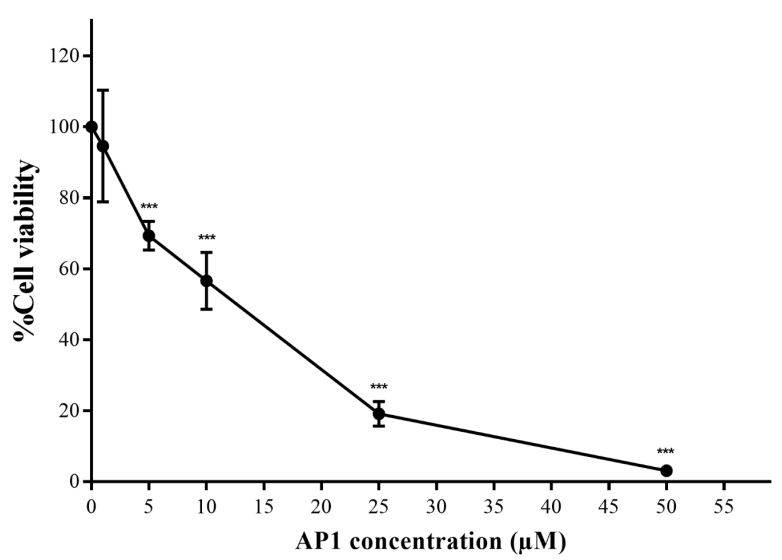

Figure 2. The Cytotoxicity of $\mathrm{AP}_{1}$ in AS52 Cells. Cells were treated with various concentrations of AP $(1-50$ $\mu \mathrm{M})$ for $24 \mathrm{~h}$, after which the cell viability was measured with the TM assay. The results are presented as mean \pm $\mathrm{SEM}, \mathrm{N}=3 . * * * \mathrm{p}<0.001$ compared with the control (untreated group).

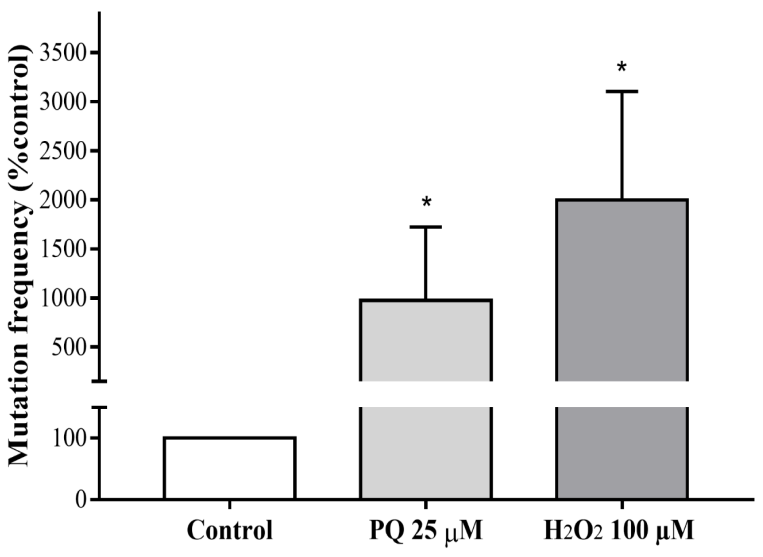

Figure 3. The Mutagenicity of PQ in AS52 Cells. PQ was mutagenic as evidenced by the increased fraction of 6-TGr mutants. Cells were treated with PQ $25 \mu \mathrm{M}$ for $24 \mathrm{~h}$, or $\mathrm{H}_{2} \mathrm{O}_{2} 100 \mu \mathrm{M}$ for $1 \mathrm{~h}$ (positive control). The results are presented as mean $\pm \mathrm{SEM}, \mathrm{N}=3$. $* \mathrm{p}<0.05$ compared with the control (untreated group).

at the highest dose of $50 \mu \mathrm{M}$ viability was only $3.1 \%$ (Figure 2).

\section{$P Q$ increased mutation frequency in AS52 cells}

The mutagenic ability of PQ was evaluated by counting the 6-TG resistant (6-TGR) colonies relative to the total number of colony-forming units plated. AS52 cells were treated with $25 \mu \mathrm{M}$ PQ for $24 \mathrm{~h}$. For a positive control, a 1 hour treatment with $\mathrm{H}_{2} \mathrm{O}_{2}(100 \mu \mathrm{M})$ was performed. As shown in Figure 3, PQ exposure led to a significant increase in mutation frequency. The positive control also generated a statistically significant increase in the number of 6-TGR colonies (Figure 3), consistent with previously reported data (Kim et al., 2003).

AP1 did not increase mutation frequency in AS52 cells

When the mutagenesis assay was repeated with $\mathrm{AP}_{1}$ and NAC compounds alone, no significant differences in mutation frequencies between the treated groups ( $\mathrm{AP}_{1}$ and NAC) and controls were observed. Neither $\mathrm{AP}_{1}$ at 1

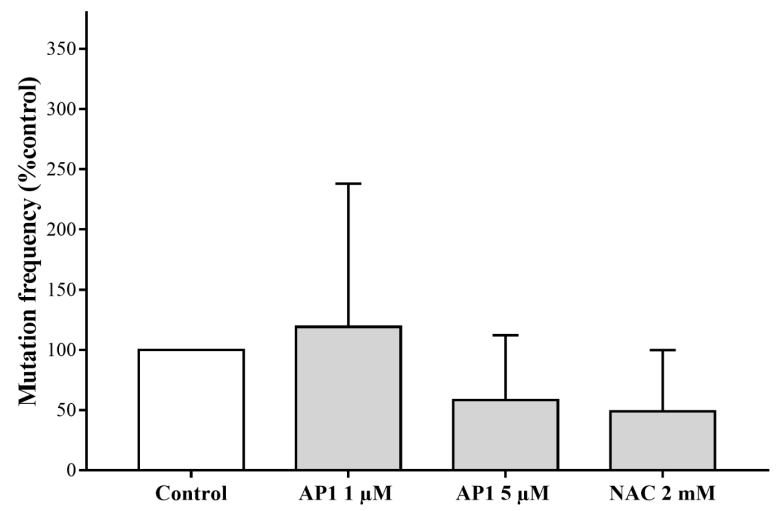

Figure 4. The Mutagenicity of the Antioxidants AP and NAC in AS52 Cells. Cells were treated with $\mathrm{AP}_{1}(1$ and $5 \mu \mathrm{M})$ and NAC ( $2 \mathrm{mM})$ for $24 \mathrm{~h}$. No significant differences in mutation frequency were observed between the treated cells and control. The results are presented as mean \pm SEM, $N=3$. ${ }^{*} \mathrm{p}<0.05$ compared with the control (untreated group). 


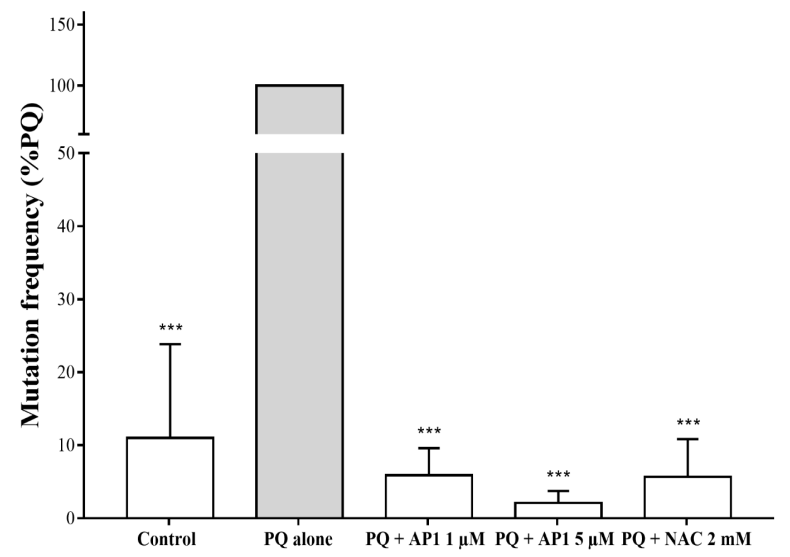

Figure 5. Antioxidants AP and NAC Counteract PQInduced Mutagenesis. AS52 cells were treated with PQ $25 \mu \mathrm{M}$, the combination of PQ $25 \mu \mathrm{M}+\mathrm{AP} 1 \mu \mathrm{M}, \mathrm{PQ} 25$ $\mu \mathrm{M}+\mathrm{AP}_{1} 5 \mu \mathrm{M}$, and PQ $25 \mu \mathrm{M}+\mathrm{NAC} 2 \mathrm{mM}$ for $24 \mathrm{~h}$. Both antioxidants significantly decreased the number of 6-TGr mutants caused by PQ. No significant differences in mutation frequency were observed between the combination of $\mathrm{PQ}+\mathrm{AP}_{1}$ and control (untreated group). The results are presented as mean $\pm \mathrm{SEM}, \mathrm{N}=3$. ***p $<0.001$ compared with the PQ treatment group (\%PQ).

$\mu \mathrm{M}$ and $5 \mu \mathrm{M}$, nor NAC at $2 \mathrm{mM}$ increased the mutation frequency compared with the untreated group (Figure 4).

\section{$A P 1$ and NAC decreased the mutagenesis of PQ in AS52 cells}

Antioxidants $\mathrm{AP}_{1}$ and NAC significantly decreased the mutagenesis of PQ. NAC, a prodrug of the natural amino acid L-cysteine, can act both directly as a free radical scavenger, reducing the available concentration of ROS, and as a cysteine source which helps restore and boost the levels of glutathione, the main cellular antioxidant. AS52 cells were treated with PQ $25 \mu \mathrm{M}$, the combination of PQ $25 \mu \mathrm{M}+\mathrm{AP}_{1} 1 \mu \mathrm{M}$, PQ $25 \mu \mathrm{M}+\mathrm{AP}_{1} 5 \mu \mathrm{M}$, and PQ 25 $\mu \mathrm{M}+\mathrm{NAC} 2 \mathrm{mM}$ for $24 \mathrm{~h}$. While the exposure of AS52 cells to $25 \mu \mathrm{M}$ of PQ generated a significantly increased mutational frequency compared to baseline (Figure 3), the co-treatment with $\mathrm{AP}_{1}$ and NAC completely abrogated the PQ-induced mutagenesis. The mutation frequency in the antioxidant co-treated cells was 20-100 fold lower than the PQ treatment group (Figure 5), a level indistinguishable from the mutation frequency in untreated AS52 cells.

The best antioxidant adjuvant $\left(\mathrm{AP}_{1}\right.$ at $\left.5 \mu \mathrm{M}\right)$ was beneficial over a wider range of $\mathrm{PQ}$ concentrations. When exposing AS52 cells to PQ alone at concentrations ranging from $10-100 \mu \mathrm{M}$ for $24 \mathrm{~h}$, the mutation frequency increased from $\sim 96$-TGR colonies per $10^{5}$ cells plated (the detection limit of the assay) to 4866 -TGR colonies per $10^{5}$ cells plated. Co-treatment with $\mathrm{AP}_{1}$ at $5 \mu \mathrm{M}$ completely abrogated PQ-induced mutations over the entire dose range of $\mathrm{PQ}$ (Figure 6). Taken together, these observations support the hypothesis that the antioxidant $\mathrm{AP}_{1}$ is effective at counteracting PQ mutagenesis in mammalian cells.

\section{Discussion}

The central goal of this study was to investigate

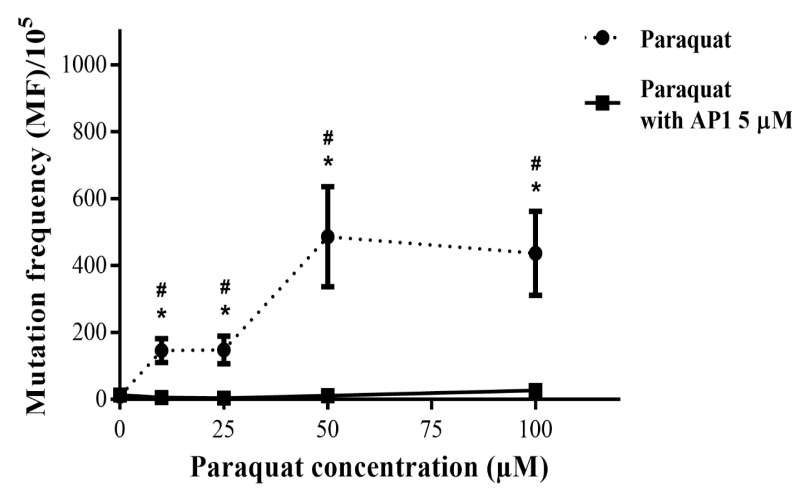

Figure 6. $\mathrm{AP}_{1} 5 \mu \mathrm{M}$ is Anti-Mutagenic Over a Wide Range of PQ Concentrations. AS52 cells were treated with PQ (10-100 $\mu \mathrm{M})$ for $24 \mathrm{~h}$ and the combination of PQ $(10-100 \mu \mathrm{M})+\mathrm{AP}_{1} 5 \mu \mathrm{M}$ for $24 \mathrm{~h}$. AP $5 \mu \mathrm{M}$ significantly decreased the number of 6-TGr mutants caused by PQ alone. The results are presented as mean $\pm \mathrm{SEM}, \mathrm{N}=3 . *_{\mathrm{p}}<0.05$ compared with the control (untreated group). $\# \mathrm{p}<0.05$ compared with the PQ + $\mathrm{AP}_{1}$ co-treatment.

the protective effect of $\mathrm{AP}_{1}$ against $\mathrm{PQ}$-induced mutagenesis. The previously documented antioxidant and anti-inflammatory properties of $\mathrm{AP}_{1}$ have suggested that this diterpenoid could be effective at preventing the toxic and mutagenic properties of a redox cycling molecule such as PQ, but direct evidence to that effect has been lacking.

The present study showed that $\mathrm{AP}_{1}$ was cytotoxic to AS52 cells in a dose-dependent manner, an observation consistent with previously reported data documenting the cytotoxic effect of both A. paniculata extracts and purified AP (Suriyo et al., 2014; Banerjee et al., 2016; Monger et al., 2017; Islam et al., 2018; Khan et al., 2018). High doses of $\mathrm{AP}_{1}$ have been found to be cytotoxic to most mammalian cell lines (Islam et al., 2018), through a mechanisms that involves disruption of mitochondrial membrane potential (Banerjee et al., 2016), cell cycle arrest (Suriyo et al., 2014; Banerjee et al., 2016) and apoptosis (Suriyo et al., 2014; Banerjee et al., 2016; Monger et al., 2017) due to immune system mediated effects (Islam et al., 2018). These observations highlight the importance of properly dosing $\mathrm{AP}_{1}$ for therapeutic purposes.

Our results here extend our previous study where we demonstrated that the mutagenicity of PQ is caused by its ability to generate oxidative stress and subsequent oxidative DNA damage such as the mutagenic base $80 \mathrm{O}$ (Tajai et al., 2018). In agreement with our previously reported data, we show here that PQ is mutagenic in AS52 wild-type cells. PQ mutagenesis presumably reflects the formation of oxidative DNA lesions, because, as we previously reported, the PQ-induced mutation frequency increases significantly in engineered cells that lack the DNA repair proteins necessary for fixing oxidative DNA damage (Tajai et al., 2018). Additionally, the PQ-induced mutagenesis is alleviated by the presence of antioxidants. Our previous work (also confirmed here) demonstrated that NAC co-treatment counteracts mutagenicity of PQ (Tajai et al., 2018). The present work demonstrates for the 
first time that supplementation with $\mathrm{AP}_{1}$ is also effective at counteracting PQ-induced mutagenesis in the AS52 cells. The mechanism of $\mathrm{AP}_{1}$ likely involves both the direct scavenging of ROS and the activation of the Nrf2 pathway that stimulates the production of antioxidant enzymes. $\mathrm{AP}_{1}$ has been shown to have free radical scavenging activities (Lin et al., 2009) and to potently upregulate Nrf2 mRNA expression (Wong et al., 2016; Seo et al., 2017; Wong et al., 2018).

There is increasing evidence that chronic exposure to PQ is associated with an increased cancer incidence (Jee et al., 1995; Wesseling et al., 1996), presumably due in part to the mutagenic properties of PQ. Many studies have proposed compounds with antioxidant activity as alternative treatments for PQ poisoning (Kim et al., 2003; Podder et al., 2012; Kim et al., 2013; Zerin et al., 2013; Blanco-Ayala et al., 2014; Ortiz et al., 2016). Our present work adds $\mathrm{AP}_{1}$ to that list. From a toxicological standpoint, we show here that in vitro $\mathrm{AP}_{1}$ by itself was not mutagenic in AS52 cells at doses effective against PQ exposure. Thus, $\mathrm{AP}_{1}$ appears to be safe within the window of efficacy. However, long term in vivo studies are needed to define and confirm its safety profile.

In conclusion, this investigation indicates that andrographolide $\left(\mathrm{AP}_{1}\right)$, and by extension, $\mathrm{AP}_{1}$-containing extracts from $A$. paniculata could be useful as alternative treatments for PQ poisoning due to their potent antioxidant activity that alleviates the PQ-induced oxidative stress and mutagenesis.

\section{Acknowledgements}

Support for this work was provided by a grant from Graduate Program in Environmental Toxicology, Chulabhorn Graduate Institute (23/2555) and Center of Excellence on Environmental Health and Toxicology, Ministry of Education, Bangkok, Thailand. Support was also provided by the US National Institutes of Health (grants P30-ES002109, R01-CA080024 and P01CA26731). The authors thank Dr. Piyajit Watcharasit for special guidance and helpful discussions.

\section{Abbreviations}

8OG, 8-oxoguanine (or 7,8-dihydro-8-oxoguanine); $\mathrm{AP}_{1}$, andrographolide; gpt, xanthine-guanine phosphoribosyltransferase; NAC, N-acetyl-L-cysteine; $P Q$, paraquat; ROS, reactive oxygen species.

\section{Statement conflict of interest}

The authors state that they have no conflicts of interest.

\section{References}

Al-Henhena N, Ying RP, Ismail S, et al (2014). Chemopreventive efficacy of Andrographis paniculata on azoxymethaneinduced aberrant colon crypt foci in vivo. PLoS One, 9, e111118.

Banerjee M, Chattopadhyay S, Choudhuri T, et al (2016). Cytotoxicity and cell cycle arrest induced by andrographolide lead to programmed cell death of MDA-MB-231 breast cancer cell line. J Biomed Sci, 23, 40.

Blanco-Ayala T, Anderica-Romero AC, Pedraza-Chaverri J
(2014). New insights into antioxidant strategies against paraquat toxicity. Free Radic Res, 48, 623-40.

Chen HW, Huang YJ, Yao HT, et al (2012). Induction of Nrf2-dependent antioxidation and protection against carbon tetrachloride-induced liver damage by Andrographis Herba (chuan xin lian) ethanolic extract. J Tradit Complement Med, 2, 211-9.

Cocheme HM, Murphy MP (2008). Complex I is the major site of mitochondrial superoxide production by paraquat. $J$ Biol Chem, 283, 1786-98.

Islam MT, Ali ES, Uddin SJ, et al (2018). Andrographolide, a diterpene lactone from Andrographis paniculata and its therapeutic promises in cancer. Cancer Lett, 420, 129-45.

Jee SH, Kuo HW, Su WP, et al (1995). Photodamage and skin cancer among paraquat workers. Int J Dermatol, 34, 466-9.

Jovtchev G, Gateva S, Stergios M, et al (2010). Cytotoxic and genotoxic effects of paraquat in Hordeum vulgare and human lymphocytes in vitro. Environ Toxicol, 25, 294-303.

Khan I, Khan F, Farooqui A, et al (2018). Andrographolide exhibits anticancer potential against human colon cancer cells by inducing cell cycle arrest and programmed cell death via augmentation of intracellular reactive oxygen species level. Nutr Cancer, 70, 787-803.

Kim HW, Murakami A, Williams MV, et al (2003). Mutagenicity of reactive oxygen and nitrogen species as detected by co-culture of activated inflammatory leukocytes and AS52 cells. Carcinogenesis, 24, 235-41.

Kim YS, Zerin T, Song HY (2013). Antioxidant action of ellagic acid ameliorates paraquat-induced A549 cytotoxicity. Biol Pharm Bull, 36, 609-15.

Lin FL, Wu SJ, Lee SC, et al (2009). Antioxidant, antioedema and analgesic activities of Andrographis paniculata extracts and their active constituent andrographolide. Phytother Res, 23, 958-64.

Low M, Khoo CS, Munch G, et al (2015). An in vitro study of anti-inflammatory activity of standardised Andrographis paniculata extracts and pure andrographolide. BMC Complement Altern Med, 15, 18.

Monger A, Boonmuen N, Suksen K, et al (2017). Inhibition of topoisomerase IIalpha and induction of apoptosis in gastric cancer cells by 19-triisopropyl andrographolide. Asian Pac J Cancer Prev, 18, 2845-51.

Ortiz MS, Forti KM, Suarez Martinez EB, et al (2016). Effects of antioxidant $\mathrm{N}$-acetylcysteine against paraquat-induced oxidative stress in vital tissues of mice. Int J Sci Basic Appl Res, 26, 26-46.

Pholphana N, Rangkadilok N, Saehun J, et al (2013). Changes in the contents of four active diterpenoids at different growth stages in Andrographis paniculata (Burm.f.) Nees (Chuanxinlian). Chin Med, 8, 2.

Podder B, Kim YS, Zerin T, et al (2012). Antioxidant effect of silymarin on paraquat-induced human lung adenocarcinoma A549 cell line. Food Chem Toxicol, 50, 3206-14.

Seo JY, Pyo E, An JP, et al (2017). Andrographolide activates Keap1/Nrf2/ARE/HO-1 pathway in HT22 cells and suppresses microglial activation by Abeta42 through Nrf2related inflammatory response. Mediators Inflamm, 2017, 5906189.

Sheeja K, Kuttan G (2007). Activation of cytotoxic T lymphocyte responses and attenuation of tumor growth in vivo by Andrographis paniculata extract and andrographolide. Immunopharmacol Immunotoxicol, 29, 81-93.

Sheeja K, Shihab PK, Kuttan G (2006). Antioxidant and antiinflammatory activities of the plant Andrographis paniculata Nees. Immunopharmacol Immunotoxicol, 28, 129-40.

Speit G, Haupter S, Hartmann A (1998). Evaluation of the genotoxic properties of paraquat in V79 Chinese hamster 
cells. Mutat Res, 412, 187-93.

Suriyo T, Pholphana N, Rangkadilok N, et al (2014). Andrographis paniculata extracts and major constituent diterpenoids inhibit growth of intrahepatic cholangiocarcinoma cells by inducing cell cycle arrest and apoptosis. Planta Med, 80, 533-43.

Tajai P, Fedeles BI, Suriyo T, et al (2018). An engineered cell line lacking OGG1 and MUTYH glycosylases implicates the accumulation of genomic 8-oxoguanine as the basis for paraquat mutagenicity. Free Radic Biol Med, 116, 64-72.

Tindall KR, Stankowski LF, Jr. (1989). Molecular analysis of spontaneous mutations at the gpt locus in Chinese hamster ovary (AS52) cells. Mutat Res, 220, 241-53.

Tindall KR, Stankowski LF, Jr., Machanoff R, et al (1986). Analyses of mutation in pSV2gpt-transformed CHO cells. Mutat Res, 160, 121-31.

Wattanawaraporn R, Kim MY, Adams J, et al (2012). AFB(1)-induced mutagenesis of the gpt gene in AS52 cells. Environ Mol Mutagen, 53, 567-73.

Wesseling C, Ahlbom A, Antich D, et al (1996). Cancer in banana plantation workers in Costa Rica. Int J Epidemiol, 25, 1125-31.

Wong DPW, Ng MY, Leung JY, et al (2018). Regulation of the NRF2 transcription factor by andrographolide and organic extracts from plant endophytes. PLoS One, 13, e0204853.

Wong SY, Tan MG, Wong PT, et al (2016). Andrographolide induces Nrf2 and heme oxygenase 1 in astrocytes by activating p38 MAPK and ERK. $J$ Neuroinflammation, 13, 251.

Yoopan N, Thisoda P, Rangkadilok N, et al (2007). Cardiovascular effects of 14-deoxy-11,12-didehydroandrographolide and Andrographis paniculata extracts. Planta Med, 73, 503-11.

Zerin T, Kim YS, Hong SY, et al (2013). Quercetin reduces oxidative damage induced by paraquat via modulating expression of antioxidant genes in A549 cells. J Appl Toxicol, 33, 1460-7.

\section{(c) (i) (8)}

This work is licensed under a Creative Commons AttributionNon Commercial 4.0 International License. 